\title{
THE IMPACT OF DIFFERENT TYPES OF FOLIAR FEEDING ON THE ARCHITECTURE ELEMENTS OF A WINTER RAPE (BRASSICA NAPUS L.) FIELD
}

\author{
SIKORSKA, A. ${ }^{1}-$ GUGAEA, $^{\text {M. }^{2}}-$ ZARZECKA, K. $^{2}$ \\ ${ }^{1}$ Department of Agriculture, Vocational State School of Ignacy Mościcki in Ciechanów, \\ ul. Narutowicza 9, 06-400 Ciechanów, Poland \\ (e-mail: anna.sikorska@puzim.edu.pl) \\ ${ }^{2}$ Faculty of Agrobioengineering and Animal Husbandry, University of Natural Sciences and \\ Humanities in Siedlce, ul. Prusa 14, 08-110 Siedlce, Poland \\ ul. Prusa 14, 08-110 Siedlce, Poland \\ (e-mail: gugala@uph.edu.pl; kzarzecka@uph.edu.pl) \\ *Corresponding author \\ e-mail: gugala@uph.edu.pl
}

(Received $1^{\text {st }}$ Aug 2019; accepted $14^{\text {th }}$ Nov 2019)

\begin{abstract}
The field experiment was carried out in 2016-2019 at the Agricultural Experimental Station Zawady $\left(52^{\circ} 03^{\prime} \mathrm{N}\right.$ and $\left.22^{\circ} 33^{\prime} \mathrm{E}\right)$ belonging to the University of Natural Sciences and Humanities in Siedlce, Poland. The experiment was established in a random layout (split - plot) with triplicates. The examined factors were I - three varieties of winter rape: Monolit, PX115, PT248. II - four types of foliar feeding: 1. control object, 2. biostimulator Aminoplant, 3. Foliar fertilizer Siarkomag + foliar fertilizer Bormax, 4. Foliar fertilizer Siarkomag + foliar fertilizer Bormax + biostimulator Aminoplant. The aim of the study was to determine the effect of foliar fertilizers containing amino acids, sulphur and boron on planting before harvest, plant height before harvest, root thickness, height to the first productive branching, deflection of three varieties of winter rape. The use of the Aminoplant biostimulator in combination with foliar fertilizers containing sulphur and boron significantly increased the planting density, the stem thickness at the root, the height to the first productive branching, compared to the control treatment. Foliar application of amino acids, boron, sulphur did not significantly increase the height of plants before harvesting and did not affect the deflection of the field.

Keywords: plant density, plant height, stem thickness, height to the first productive branching, plant morphology before harvest, field deflection
\end{abstract}

\section{Introduction}

Currently, one of the basic elements of agrotechnics of many crops is foliar feeding. This treatment entails the introduction of deficient nutrients to aboveground parts of plants (Szewczuk and Sugier, 2009). Singh et al. (2013) state that this is an alternative way to provide plants with missing macro and micronutrients consisting of sprinkling leaves with a dilute solution of mineral salts, chelates with the addition of a surface tension reducing agent. According to many authors (Fageria et al., 2009; Singh et al., 2013), foliar nutrition affects the correction of poor nutritional status of plants.

Kinaci and Gulmezoglu (2007) and Babaeian et al. (2011) believe that foliar spraying is very beneficial when the roots cannot provide the necessary nutrients to the plants, due to improper soil $\mathrm{pH}(\mathrm{pH})$, drying time, and heavy texture. Similarly, Kocoń (2009) emphasizes that it is much more beneficial to apply foliar spray instead of direct soil application.

According to Kaur et al. (2019), foliar feeding plays a significant role in areas with changing climatic conditions. Stress caused by drought reduces both uptake of nutrients 
through the roots and transport from roots to shorts, due to limited transpiration and weakened active transport (Yuncai and Schmidhalter, 2005). Well-nourished plants with essential nutrients are more resistant to abiotic stresses.

The reaction of plants to foliar nutrition varies greatly between plant species, growth stages, the concentration of the added nutrient solution and the relative water content in plant parts (Noreen et al., 2018).

The paper assumes a research hypothesis that biostimulators combined with foliar feeding can have a beneficial effect on the architectural elements of winter rape fields.

The aim of the study was to determine the effect of foliar fertilizers containing amino acids, sulphur, boron on planting before harvest, plant height before harvest, root thickness, height to the first productive branching, deflection of three varieties of winter rape (Monolit, PX115, PT248).

\section{Materials and methods}

\section{Experimental and agronomic management}

The field experiment was carried out in 2016-2019 at the Agricultural Experimental Station Zawady $\left(52^{\circ} 03^{\prime} \mathrm{N}\right.$ and $\left.22^{\circ} 33^{\prime} \mathrm{E}\right)$ belonging to the University of Natural Sciences and Humanities in Siedlce, Poland. The experiment was established in a random layout (split - plot) in triplicate. The surface of each plot was $21 \mathrm{~m}^{2}$. Table 1 presents the agrotechnical factors included in the experiment.

Table 1. Agrotechnical factors included in the experiment (RSD Zawady)

\begin{tabular}{|c|c|}
\hline \multicolumn{2}{|r|}{ Agrotechnical factors } \\
\hline $\begin{array}{c}\text { Three } \\
\text { morphotypes }\end{array}$ & $\begin{array}{l}\text { - Population morphotype (Monolit variety) } \\
\text { - Restored morphotype with the traditional growth type (PT248) } \\
\text { - Restored morphotype with semi-dwarf growth type (PX115 variety) }\end{array}$ \\
\hline $\begin{array}{l}\text { Four types of } \\
\text { foliar feeding }\end{array}$ & 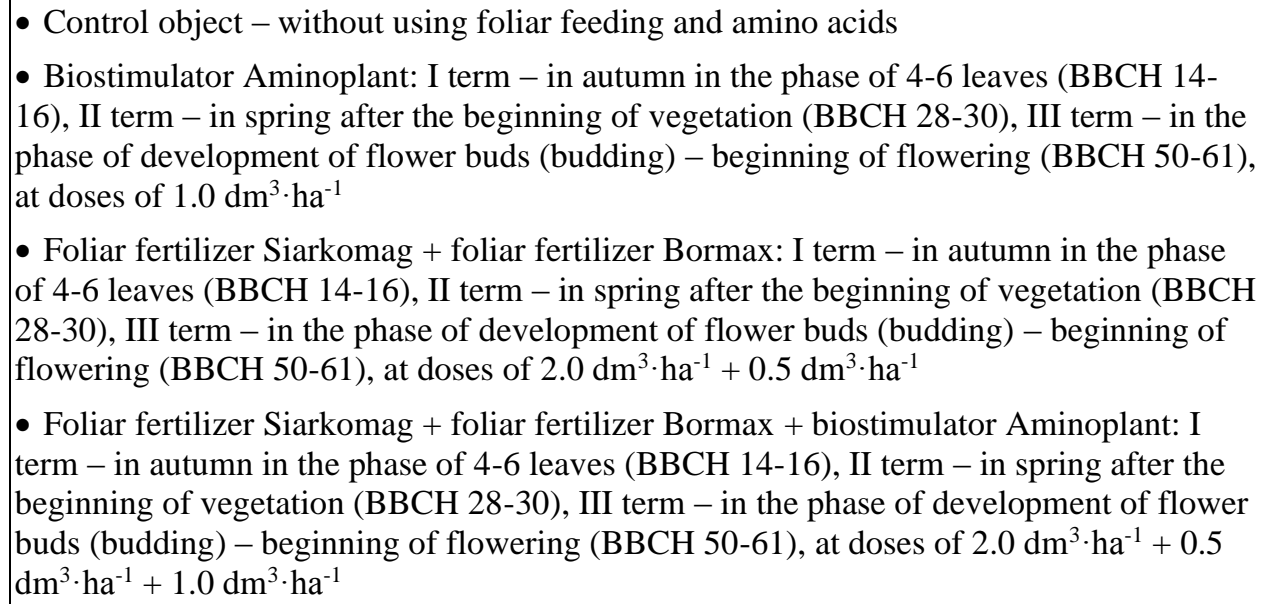 \\
\hline
\end{tabular}

In the 2016-2017 growing season, the forecrop for winter rape was spring wheat, in the second and final year of research - winter triticale. The experiment was carried out on soil classified according to the World reference base for soil resources (2014) to the Haplic Luvisol group, sated, belonging to the very good rye soil complex, Iva valuation class. During the research years, the soil $\mathrm{pH}(\mathrm{pH}$ in $1 \mathrm{~N} \mathrm{KCl})$ was slightly acidic and 
ranged from 5.68 to 5.75 . The soil was characterised by a low total nitrogen content (average from 0.80 to $0.90 \mathrm{~g} \cdot \mathrm{kg}^{-1}$ ), phosphorous content (average from 0.33 to $0.55 \mathrm{~g} \cdot \mathrm{kg}^{-1}$ ), potassium content (average from 0.61 to $0.67 \mathrm{~g} \cdot \mathrm{kg}^{-1}$ ) and calcium content (average from 0.82 to $0.85 \mathrm{~g} \cdot \mathrm{kg}^{-1}$ ) and the average magnesium content (from 0.38 to $0.46 \mathrm{~g} \cdot \mathrm{kg}^{-1}$ ) and sulphur content (from 0.11 to $0.15 \mathrm{~g} \cdot \mathrm{kg}^{-1}$ ).

The soil was characterized by low abundance in available forms of phosphorus and average bioavailability in potassium and magnesium (Table 2).

Table 2. Characteristics of soil conditions - Zawady Meteorological Station, Poland (20162019)

\begin{tabular}{|c|c|c|c|c|}
\hline \multirow{2}{*}{ Vegetation seasons } & \multirow{2}{*}{$\begin{array}{c}\text { pH } \\
\left(1 \mathrm{~mol} \cdot \mathbf{d m}^{-3} \mathrm{KCl}\right)\end{array}$} & \multicolumn{3}{|c|}{ The content of available forms of elements $\left(\mathrm{mg} \cdot \mathrm{kg}^{-1}\right)$} \\
\hline & & $\mathbf{P}$ & $\mathbf{K}$ & Mg \\
\hline $2016-2017$ & 5.70 & 81.0 & 200.0 & 63.0 \\
\hline 2017-2018 & 5.68 & 75.0 & 199.0 & 60.0 \\
\hline 2018-2019 & 5.75 & 79.0 & 202.0 & 59.0 \\
\hline
\end{tabular}

After forecrop harvest, a set of post-harvest procedures was carried out using the ploughing aggregate + open cage roller, and then two weeks after the first procedure, pre-sow ploughing at the depth of $20.0 \mathrm{~cm}$ was carried out, using a ring roller at the same time. To prepare the soil for sowing and to mix fertilizers, a complex soil tillage unit was used. Before sowing, phosphorus-potassium fertilization was applied at the dose of $40 \mathrm{~kg} \mathrm{P} \cdot \mathrm{ha}^{-1}$ and $110 \mathrm{~kg} \mathrm{~K} \cdot \mathrm{ha}^{-1}$ and the first dose of $40 \mathrm{~kg} \mathrm{~N} \cdot \mathrm{ha}^{-1}$. Fertilization was applied in the form of Lubofos at the dose of $600 \mathrm{~kg}$. Fertilizing doses were supplemented with $55.9 \mathrm{~kg} \cdot \mathrm{ha}^{-1}$ of ammonium nitrate $\left(19 \mathrm{~kg} \mathrm{~N} \cdot \mathrm{ha}^{-1}\right), 29.6 \mathrm{~kg} \cdot \mathrm{ha}^{-1}$ triple superphosphate $\left(13.6 \mathrm{~kg} \mathrm{P} \cdot \mathrm{ha}^{-1}\right)$ and $29 \mathrm{~kg} \cdot \mathrm{ha}^{-1}$ potassium salt $\left(17.9 \mathrm{~kg} \mathrm{~K} \cdot \mathrm{ha}^{-1}\right)$. The second dose of nitrogen in the amount of $100 \mathrm{~kg} \cdot \mathrm{ha}^{-1}$ was applied in spring, before vegetation started (BBCH 28-30) applying ammonium nitrate at the dose of $255.5 \mathrm{~kg} \cdot \mathrm{ha}^{-1}\left(86.9 \mathrm{~kg} \mathrm{~N} \cdot \mathrm{ha}^{-1}\right)$ and ammonium sulphate at the dose of $62.5 \mathrm{~kg} \cdot \mathrm{ha}^{-1}$. The third dose of ammonium $60 \mathrm{~kg} \cdot \mathrm{ha}^{-1}$ was applied at the inflorescence emergence (BBCH $50)$. by applying ammonium nitrate at the dose of $176.5 \mathrm{~kg} \cdot \mathrm{ha}^{-1}\left(60 \mathrm{~kg} \mathrm{~N} \cdot \mathrm{ha}^{-1}\right)$.

Winter rapeseed sowing was made at spacing between rows of $22.5 \mathrm{~cm}$, assuming a case of $60 \mathrm{pcs} \cdot \mathrm{m}^{-2}$. Sowing was made at the optimal time recommended for this region (in 2016 - on August 12, in 2017 - on August 14, and in 2018 - on August 13).

Chemical protection against weeds, diseases and pests was applied in accordance with the recommendations of good agricultural practice. Directly after sowing, herbicide Command $480 \mathrm{EC}$ at the dose of $0.25 \mathrm{dm}^{3} \cdot \mathrm{ha}^{-1}$ was applied to carefully cultivated soil. Next, at the stage of BBCH 13-14, Fusilade Forte $150 \mathrm{EG}$ at the dose of $2.0 \mathrm{dm}^{3} \cdot \mathrm{ha}^{-1}$ was applied. At the 4-8 leaves unfolded stage (BBCH 14-18) fungicide Horizon $250 \mathrm{EW}$ was applied $\left(0.75 \mathrm{dm}^{3} \cdot \mathrm{ha}^{-1}\right)$. At the stem elongation stage (BBCH 30), flower bud emergence stage (BBCH 50-58), flowering (BBCH 60-69) - Proteus 110 OD insecticide was applied at the dose of $0.6 \mathrm{dm}^{3} \cdot \mathrm{ha}^{-1}$. At the beginning of flowering (BBCH 61) - Propulse 250 SE fungicide was applied at the dose of $1.0 \mathrm{dm}^{3} \cdot \mathrm{ha}^{-1}$. At the stage of first petals falling - Mondatak $450 \mathrm{EC}$ was applied at the dose of $1.0 \mathrm{dm}^{3} \cdot \mathrm{ha}^{-1}$.

Rape was harvested in two stages in the first and second decade of July.

Immediately prior to harvest (BBCH 86-87) the case per $1 \mathrm{~m}^{-2}$ was marked and elements of field architecture were determined for a sample of 20 plants from each plot, such as:

- Plant height before harvest $(\mathrm{cm})$ 
- Stem thickness at the base (mm)

- Height of seating of the first productive branch $(\mathrm{cm})$

- Field deflection $(\%)$

\section{Weather conditions in vegetation period}

During the years of conducting the experiment, varied weather conditions prevailed (Table 3). In the first vegetation period, the annual precipitation totalled $389.2 \mathrm{~mm}$ and was $8.9 \%$ lower compared to the multi-annual average $(427.5 \mathrm{~mm})$, while the average air temperature was similar and amounted to $7.9^{\circ} \mathrm{C}$. Based on the calculated Sielianinov hydrothermal coefficient, it was found that the years 2016-2017 and 2017-2018 were optimal. In the second year of research, the largest annual precipitation was recorded (414.5 mm), $13 \mathrm{~mm}$ lower than the average for 1996-2010, while the average air temperature was higher by $1{ }^{\circ} \mathrm{C}$ and amounted to $9.3{ }^{\circ} \mathrm{C}$. The last year of research was the most dry and warm. The annual amount of rainfall was lower by $174.6 \mathrm{~mm}$, while the temperature was higher than the long-term average by $1.6^{\circ} \mathrm{C}$.

Table 3. Characteristics of weather conditions in the years 2016-2019 (Zawady Meteorological Station, Poland)

\begin{tabular}{|c|c|c|c|c|c|c|c|c|c|c|c|c|c|}
\hline \multirow{2}{*}{ Years } & \multicolumn{13}{|c|}{ Months } \\
\hline & VIII & $\mathbf{I X}$ & $\mathbf{X}$ & $\mathbf{X I}$ & XII & $\mathbf{I}$ & II & III & IV & $\mathbf{V}$ & VI & VII & VIII-VII \\
\hline \multicolumn{13}{|c|}{ Rainfalls (mm) } & Sum \\
\hline $2016-2017$ & 31.7 & 13.6 & 69.8 & 19.5 & 22.5 & 0.4 & 15.9 & 25.1 & 59.7 & 49.5 & 57.9 & 23.6 & 389.2 \\
\hline 2017 & 54.7 & 80.6 & 53.0 & 21.3 & 15.8 & 10.1 & 3.2 & 15.4 & 34.5 & 27.3 & 31.5 & 67.1 & 414.5 \\
\hline 2018-2019 & 24.5 & 27.4 & 23.3 & 9.8 & 9.0 & 7.9 & 4.7 & 15.0 & 5.9 & 59.8 & 35.9 & 29.7 & 252.9 \\
\hline $\begin{array}{c}\text { Multiyear sum } \\
(1996-2010)\end{array}$ & 59.9 & 42.3 & 24.2 & 20.2 & 18.6 & 19.0 & 16.0 & 18.3 & 33.6 & 58.3 & 59.6 & 57.5 & 427.5 \\
\hline \multicolumn{13}{|c|}{ Air temperature $\left({ }^{\circ} \mathbf{C}\right)$} & Mean \\
\hline $2016-2017$ & $\mid 18.0$ & 14.9 & 7.0 & 2.4 & 0.0 & -6.6 & -1.3 & 5.5 & 6.9 & 13.9 & 17.8 & 16.9 & 7.9 \\
\hline & 18.4 & 13.9 & 9.0 & 4.1 & 2.7 & -0.7 & -4.0 & -0.3 & 13.1 & 17.0 & 18.3 & 20.4 & 9.3 \\
\hline 2018 & 20.6 & 15.9 & 9.6 & 7.9 & 0.3 & -3.0 & 2.2 & 4.8 & 9.8 & 13.3 & 17.9 & 18.5 & 9.8 \\
\hline $\begin{array}{c}\text { Multiyear mean } \\
(1996-2010) \\
\end{array}$ & 18.5 & 13.5 & 7.9 & 4.0 & -0.1 & -3.2 & -2.3 & 2.4 & 8.0 & 13.5 & 17.0 & 19.7 & 8.2 \\
\hline \multicolumn{14}{|c|}{ Sielianinovs hydrothermic coefficients* } \\
\hline & \multicolumn{2}{|c|}{ VIII } & \multicolumn{2}{|c|}{ IX } & \multicolumn{3}{|c|}{$\mathbf{X}$} & III & IV & $\mathbf{V}$ & VI & VII & Mean \\
\hline 2016-2017 & \multirow{2}{*}{\multicolumn{2}{|c|}{0.61}} & \multicolumn{2}{|c|}{0.28} & \multicolumn{3}{|c|}{3.02} & 1.79 & 3.19 & 1.52 & 1.06 & 0.47 & 1.49 \\
\hline 018 & & & \multirow{2}{*}{\multicolumn{2}{|c|}{$\begin{array}{l}1.92 \\
0.71\end{array}$}} & \multirow{2}{*}{\multicolumn{3}{|c|}{$\begin{array}{l}2.36 \\
0.94\end{array}$}} & 2.97 & 0.99 & 0.59 & 0.61 & 1.12 & 1.44 \\
\hline 2018-2019 & \multicolumn{2}{|c|}{0.40} & & & & & & 1.16 & 0.20 & 1.37 & 0.63 & 0.56 & 0.75 \\
\hline
\end{tabular}

*Index value (Skowera, 2014): Extremely dry $\mathrm{k} \leq 0.4$. Very dry $0.4<\mathrm{k} \leq 0.7$. Dry $0.7<\mathrm{k} \leq 1.0$. Rather dry $1.0<\mathrm{k} \leq 1.3$. Optimal $1.3<\mathrm{k} \leq 1.6$. Rather humid $1.6<\mathrm{k} \leq 2.0$. Humid $2.0<\mathrm{k} \leq 2.5$. very humid $2.5<\mathrm{k} \leq 3.0$. Extremely humid $\mathrm{k}>3.0$

\section{Statistical analysis}

The results of the study were statistically analysed with the use of the analysis of variance. The significance of variation sources was tested with the "F" FischerSnedecor test and the assessment of significance at the significance level of $p=0.05$ between compared means - with Tukey's range test. 


\section{Results and discussion}

Based on our own studies, it was found that the types of foliar nutrition significantly increased the number of plants determined before harvesting (Table 4). The largest plant density was recorded after the use of the Siarkomag foliar fertilizer with the Bormax foliar fertilizer and the Aminoplant biostimulator (object 4). After using the bioregulator with an amino acid, the plant density was only an average higher by one item compared to the control object. Jarecki et al. (2019) obtained a significant increase in the number of plants compared to the object without feeding after the application of the Insol5 foliar preparation in autumn, autumn and spring, autumn and twice in spring, while the value of this feature on the objects was the same. Different results were obtained by Czarnik et al. (2015) and Chwil (2016). Similarly, Jankowski et al. (2016a, b) under the influence of foliar application of boron did not find a significant effect of the factor on the value of this feature, as well as Szczepanek and Brach (2019) after the application of the Phostrade ${ }^{\circledR}$ BMo foliar preparation.

The genetic factor significantly influenced the planting before harvest (Table 4). The highest value of this feature was demonstrated in the PX115 semi-dwarf hybrid. The population variety Monolit had, on average, from 2 to 3 plants less per unit area compared to restored hybrids. Different results were obtained by Czarnik et al. (2015), who did not find significant differences between the Arot population variety and the Primus hybrid variety.

Preparations containing amino acids, sulphur and boron increased the height of plants before harvest on average from 2.3 to $5.5 \mathrm{~cm}$, but the differences between the examined objects were statistically insignificant (Table 4). Similar results were obtained by Jarecki and Bobrecka-Jamro (2008) after the application of foliar fertilizers Basfoliar 36 Extra, Basfoliar 12-4-6+S, Solubor DF, Adob Mn and mixtures of Basfoliar 36 Extra with Solubor DF, Basfoliar 12-4-6 + S with Solubor DF. Przybysz et al. (2008), Sikorska et al. (2018) after using the Asahi SL biostimulator obtained a significant increase in the plant height. Similarly, Rabiee et al. (2013), Riki et al. (2014) and Cheema et al. (2012) obtained a significant increase of this feature under the influence of foliar nutrition. Habbasha and Salam (2009) emphasized that the dual application of foliar fertilization in the rosette and budding phase has a more favourable effect on the plant height compared to the single dose used in autumn.

In own studies, the height of a hybrid with a traditional type of growth and a population variant was the same (Table 4). A similar tendency was noted by Sikorska et al. (2018), while Jarecki and Bobrecka-Jamro (2008) did not find significant differences in the amount of plants of the evaluated varieties (Lirajet, Marita, Lisek).

The application of foliar fertilization influenced the increase of stem thickness at the base from 0.42 to $10.4 \mathrm{~mm}$. The highest value of this feature was noted on object 4 after the application of Siarkomag foliar fertilizer with Bormax and Aminoplant biostimulator (Table 4).

From the compared morphotypes, the largest stem thickness at the base was distinguished among the Monolit population variety, while the smallest among the restored hybrid with a traditional growth type (Table 4). Different results were obtained by Sikorska et al. (2018). The authors recorded the largest thickness of the stem at the base of restored hybrids (PT205 and PR44D06), and significantly smaller in the Monolit population variety. 
Table 4. Plant number before harvest (pcs.), plant height before harvest (cm), stem thickness at the base $(\mathrm{mm})$ depending on factors of experience

\begin{tabular}{|c|c|c|c|c|}
\hline \multirow{2}{*}{ Types of foliar feeding } & \multicolumn{3}{|c|}{ Cultivars } & \multirow{2}{*}{ Mean } \\
\hline & Monolit & PT 248 & PX 115 & \\
\hline \multicolumn{5}{|c|}{ Plant number before harvest (pcs.) } \\
\hline 1. Control variant & 50.7 & 53.1 & 54.4 & $52.7^{\text {a }}$ \\
\hline 2. Biostimulator Aminoplant & 51.7 & 54.0 & 55.6 & $53.7^{\text {b }}$ \\
\hline $\begin{array}{l}\text { 3. Foliar fertilizer Siarkomag }+ \text { foliar fertilizer } \\
\text { Bormax }\end{array}$ & 52.9 & 55.1 & 56.1 & $54.7^{c}$ \\
\hline $\begin{array}{l}\text { 4. Foliar fertilizer Siarkomag }+ \text { foliar fertilizer } \\
\text { Bormax }+ \text { biostimulator Aminoplant }\end{array}$ & 53.6 & 55.6 & 56.6 & $55.2^{d}$ \\
\hline Mean & $52.2^{a}$ & $54.4^{b}$ & $55.7^{c}$ & - \\
\hline \multicolumn{4}{|c|}{$\begin{array}{l}\text { Cultivars } \\
\text { Types of foliar feeding } \\
\text { cultivars } x \text { types of foliar feeding }\end{array}$} & $\begin{array}{l}0.45 \\
0.57 \\
\text { n.s. }\end{array}$ \\
\hline \multicolumn{5}{|c|}{ Plant height before harvest $(\mathrm{cm})$} \\
\hline 1. Control variant & 129.9 & 126.2 & 110.2 & 122.1 \\
\hline 2. Biostimulator Aminoplant & 131.1 & 128.9 & 113.2 & 124.4 \\
\hline $\begin{array}{l}\text { 3. Foliar fertilizer Siarkomag }+ \text { foliar fertilizer } \\
\text { Bormax }\end{array}$ & 134.2 & 130.5 & 103.9 & 122.9 \\
\hline $\begin{array}{l}\text { 4. Foliar fertilizer Siarkomag + foliar fertilizer } \\
\text { Bormax }+ \text { biostimulator Aminoplant }\end{array}$ & 134.8 & 132.1 & 116.1 & 127.6 \\
\hline Mean & $132.5^{a}$ & $129.4^{\mathrm{a}}$ & $110.8^{b}$ & - \\
\hline \multicolumn{4}{|c|}{$\begin{array}{c}\text { Cultivars } \\
\text { Types of foliar feeding } \\
\text { Interaction: cultivars } x \text { types of foliar feeding }\end{array}$} & $\begin{array}{l}6.24 \\
\text { n.s. } \\
\text { n.s. }\end{array}$ \\
\hline \multicolumn{5}{|c|}{ Stem thickness at the base (mm) } \\
\hline 1. Control variant & $14.23^{\mathrm{a}}$ & $14.06^{\mathrm{ac}}$ & $14.28^{\mathrm{a}}$ & $14.19^{a}$ \\
\hline 2. Biostimulator Aminoplant & $15.06^{\text {be }}$ & $14.43^{\mathrm{ad}}$ & $14.36^{\mathrm{a}}$ & $14.61^{b}$ \\
\hline $\begin{array}{l}\text { 3. Foliar fertilizer Siarkomag }+ \text { foliar fertilizer } \\
\text { Bormax }\end{array}$ & $15.26^{\mathrm{bg}}$ & $14.48^{\mathrm{df}}$ & $14.77^{\mathrm{edf}}$ & $14.83^{c}$ \\
\hline $\begin{array}{l}\text { 4. Foliar fertilizer Siarkomag }+ \text { foliar fertilizer } \\
\text { Bormax }+ \text { biostimulator Aminoplant }\end{array}$ & $15.48^{\mathrm{g}}$ & $14.89^{\mathrm{h}}$ & $15.32^{b}$ & $15.23^{d}$ \\
\hline Mean & $15.01^{\text {a }}$ & $14.46^{b}$ & $14.68^{c}$ & - \\
\hline $\begin{array}{r}\text { LSD } 0.05 \\
\text { Cultiv } \\
\text { Types of foli } \\
\text { Interaction: cultivars x ty }\end{array}$ & feeding & ing & & $\begin{array}{l}0.23 \\
0.24 \\
0.37\end{array}$ \\
\hline
\end{tabular}

Values marked with the same letter do not differ significantly at $\mathrm{P} \leq 0.05$. n.s. - non significant differences

The effect of foliar feeding on the thickness of the stem at the base depended on the genetic factor (Table 4). The studies have shown that on the control object the differences between the tested varieties were statistically insignificant. The use of the Aminoplant biostimulator (object 2) in restored hybrids PT248 and PX115 did not significantly affect the increase of the thickness of the stem at the base when 
compared to the object on which no foliar nutrition was applied. The largest significant increase was found in the population variety after the application of the Aminoplant biostimulator with sulphur fertilizers (object 3) and sulphur and boron (object 4), while the differences between variants 3 and 4 were statistically insignificant, and in the case of restored hybrids only after the application of the Aminoplant biostimulator in connection with foliar fertilizers containing sulphur and boron.

In own studies it was found that the height to the first productive branching on control objects and the biostimulator containing amino acids was the same. The highest value of this feature was noted after the use of preparations containing sulphur (object 3) and sulphur and boron (object 4) (Table 5). Sikorska et al. (2018) after using the biostimulator Asahi SL obtained an increase in the value of this feature by an average of $4.6 \mathrm{~cm}$. While Jarecki and Bobrecka-Jamro (2008) did not find a significant influence of this factor.

The studied varieties were distinguished by varying height to the first productive branching. The highest first productive branching was noted in the population variety, significantly lower in the re-cultivated hybrid with the traditional type of growth (Table 5).

Table 5. First productive branch placement $(\mathrm{cm})$, canopy lodging $(\%)$ depending on factors of experience

\begin{tabular}{|c|c|c|c|c|}
\hline \multirow{2}{*}{ Types of foliar feeding } & \multicolumn{3}{|c|}{ Cultivars } & \multirow{2}{*}{ Mean } \\
\hline & Monolit & PT 248 & PX 115 & \\
\hline \multicolumn{5}{|c|}{ First productive branch placement $(\mathrm{cm})$} \\
\hline 1. Control variant & 46.14 & 37.82 & 36.70 & $40.22^{a}$ \\
\hline 2. Biostimulator Aminoplant & 47.77 & 39.14 & 38.66 & $41.86^{a b}$ \\
\hline $\begin{array}{l}\text { 3. Foliar fertilizer Siarkomag }+ \text { foliar fertilizer } \\
\text { Bormax }\end{array}$ & 48.74 & 40.18 & 38.99 & $42.64^{c}$ \\
\hline $\begin{array}{l}\text { 4. Foliar fertilizer Siarkomag }+ \text { foliar fertilizer } \\
\text { Bormax }+ \text { biostimulator Aminoplant }\end{array}$ & 48.68 & 40.53 & 39.78 & $43.00^{c}$ \\
\hline Mean & $47.83^{a}$ & $39.42^{b}$ & $38.53^{c}$ & - \\
\hline $\begin{array}{r}\text { LSD }_{\mathbf{0 . 0 5}} \\
\text { Cultiva } \\
\text { Types of folia } \\
\text { Interaction: cultivars x ty }\end{array}$ & $\begin{array}{l}\text { eeding } \\
\text { s of foliar }\end{array}$ & & & $\begin{array}{c}0.42 \\
0.63 \\
\text { n.s. }\end{array}$ \\
\hline \multicolumn{5}{|c|}{ Canopy lodging (\%) } \\
\hline 1. Control variant & 10.8 & 6.8 & 5.1 & 7.6 \\
\hline 2. Biostimulator Aminoplant & 10.9 & 7.1 & 6.6 & 8.2 \\
\hline $\begin{array}{l}\text { 3. Foliar fertilizer Siarkomag }+ \text { foliar fertilizer } \\
\text { Bormax }\end{array}$ & 11.8 & 7.3 & 5.7 & 8.3 \\
\hline $\begin{array}{l}\text { 4. Foliar fertilizer Siarkomag }+ \text { foliar fertilizer } \\
\text { Bormax }+ \text { biostimulator Aminoplant }\end{array}$ & 9.2 & 7.3 & 6.9 & 7.8 \\
\hline Mean & $10.7^{\text {a }}$ & $7.1^{b}$ & $6.1^{b}$ & - \\
\hline \multicolumn{4}{|c|}{$\begin{array}{c}\text { Types of foliar feeding } \\
\text { Interaction: cultivars } \mathrm{x} \text { types of foliar feeding }\end{array}$} & $\begin{array}{l}1.33 \\
\text { n.s. } \\
\text { n.s. }\end{array}$ \\
\hline
\end{tabular}

Values marked with the same letter do not differ significantly at $\mathrm{P} \leq 0.05$. n.s. - non significant differences 
The types of foliar nutrition did not affect the field deflection of the studied varieties of winter rape. Among the studied varieties, the greatest deflection of the field was recorded in the population variety, while the differences between the restored hybrids were statistically insignificant (Table 5).

Weather conditions influenced a significant diversity of morphological characteristics marked before harvest (Tables 6-7). The sum of rainfall significantly higher than the average for many years in the period from March to April in the first year of research caused that the plants grew higher, had a greater thickness of the stem at the root, developed the first productive branching higher. The smallest values of these features were noted in the last vegetation period, in which the sum of precipitation in April was lower by $82.5 \%$ compared to the average for many years, and the average air temperature higher by $1.8^{\circ} \mathrm{C}$. The largest number of plants before harvest was noted in a warm and dry vegetation period, which was characterized by a higher average air temperature from November to April and a lower amount of rainfall in this period compared to the average for many years, while the smallest cast was demonstrated in 2017-2018, characterized by lower average air temperature in the period from February to March.

Table 6. Plant number before harvest (pcs), plant height before harvest (cm), stem thickness at the base ( $\mathrm{mm})$ depending on cultivars and years

\begin{tabular}{|c|c|c|c|c|}
\hline \multirow{2}{*}{ Years } & \multicolumn{3}{|c|}{ Cultivars } & \multirow{2}{*}{ Mean } \\
\hline & Monolit & PT 248 & PX 115 & \\
\hline \multicolumn{5}{|c|}{ Plant number before harvest (pcs.) } \\
\hline $2016-2017$ & $50.2^{\mathrm{a}}$ & $54.3^{\mathrm{b}}$ & $56.1^{\mathrm{c}}$ & $53.5^{a}$ \\
\hline 2017-2018 & $49.6^{\mathrm{a}}$ & $51.3^{\mathrm{e}}$ & $52.9^{\mathrm{g}}$ & $51.3^{b}$ \\
\hline 2018-2019 & $56.8^{\mathrm{d}}$ & $57.8^{\mathrm{f}}$ & $58.0^{f}$ & $57.5^{\mathrm{c}}$ \\
\hline Mean & 52.2 & 54.4 & 55.7 & - \\
\hline \multicolumn{4}{|c|}{ LSD0.05 for: } & \\
\hline \multicolumn{4}{|c|}{ Cultivars } & 0.45 \\
\hline \multicolumn{4}{|c|}{ Years } & 0.45 \\
\hline \multicolumn{4}{|c|}{ Interaction: cultivars $\mathrm{x}$ years } & 0.77 \\
\hline \multicolumn{5}{|c|}{ Plant height before harvest $(\mathrm{cm})$} \\
\hline $2016-2017$ & 141.8 & 139.3 & 120.2 & $133.7^{a}$ \\
\hline 2017-2018 & 132.4 & 129.5 & 105.5 & $122.5^{b}$ \\
\hline 2018-2019 & 123.3 & 119.5 & 106.8 & $116.5^{b}$ \\
\hline Mean & 132.5 & 129.4 & 110.8 & - \\
\hline \multicolumn{5}{|c|}{ LSD0.05 for: } \\
\hline \multicolumn{4}{|c|}{ Cultivars } & 6.24 \\
\hline \multicolumn{4}{|c|}{ Years } & 6.24 \\
\hline \multicolumn{4}{|c|}{ Interaction: cultivars x years } & n.s. \\
\hline \multicolumn{5}{|c|}{ Stem thickness at the base (mm) } \\
\hline $2016-2017$ & 15.43 & 15.04 & 15.02 & $15.16^{\mathrm{a}}$ \\
\hline 2017-2018 & 14.99 & 14.33 & 14.59 & $14.64^{b}$ \\
\hline 2018-2019 & 14.60 & 14.03 & 14.43 & $14.35^{\mathrm{c}}$ \\
\hline Mean & 15.01 & 14.46 & 14.68 & - \\
\hline \multicolumn{4}{|c|}{ LSD $_{0.05}$ for: } & \\
\hline \multicolumn{4}{|c|}{ Cultivars } & 0.23 \\
\hline \multicolumn{4}{|c|}{ Years } & 0.23 \\
\hline \multicolumn{4}{|c|}{ Interaction: cultivars $\mathrm{x}$ years } & n.s. \\
\hline
\end{tabular}

Values marked with the same letter do not differ significantly at $\mathrm{P} \leq 0.05$. n.s. - non significant differences 
Table 7. First productive branch placement (cm), canopy lodging (\%) depending on cultivars and years

\begin{tabular}{|c|c|c|c|c|}
\hline \multirow{2}{*}{ Years } & \multicolumn{3}{|c|}{ Cultivars } & \multirow{2}{*}{ Mean } \\
\hline & Monolit & PT 248 & PX 115 & \\
\hline \multicolumn{5}{|c|}{ First productive branch placement $(\mathrm{cm})$} \\
\hline $2016-2017$ & $54.03^{\mathrm{a}}$ & $40.23^{\mathrm{d}}$ & $39.26^{\mathrm{e}}$ & $44.51^{a}$ \\
\hline $2017-2018$ & $45.58^{b}$ & $39.10^{\mathrm{e}}$ & $39.03^{\mathrm{e}}$ & $41.24^{b}$ \\
\hline 2018-2019 & $43.89^{c}$ & $38.93^{\mathrm{e}}$ & $37.30^{\mathrm{f}}$ & $40.04^{c}$ \\
\hline Mean & 47.83 & 39.42 & 38.53 & \\
\hline & $\begin{array}{l}\text { D0.05 for: } \\
\text { ultivars } \\
\text { Years } \\
\text { cultivars } x\end{array}$ & & & $\begin{array}{l}0.42 \\
0.42 \\
0.72 \\
\end{array}$ \\
\hline \multicolumn{5}{|c|}{ Canopy lodging (\%) } \\
\hline $2016-2017$ & $13.3^{\mathrm{a}}$ & $11.0^{\mathrm{b}}$ & $8.8^{c}$ & $11.0^{a}$ \\
\hline $2017-2018$ & $10.6^{\mathrm{b}}$ & $7.0^{\mathrm{c}}$ & $4.7^{\mathrm{d}}$ & $7.4^{\mathrm{b}}$ \\
\hline 2018-2019 & $8.2^{\mathrm{c}}$ & $3.3^{\mathrm{d}}$ & $4.8^{\mathrm{d}}$ & $5.4^{\mathrm{c}}$ \\
\hline Mean & 10.7 & 7.1 & 6.1 & - \\
\hline & $\begin{array}{l}\text { D..05 for: } \\
\text { ultivars } \\
\text { Years } \\
\text { cultivars X }\end{array}$ & & & $\begin{array}{c}1.33 \\
1.33 \\
2.3\end{array}$ \\
\hline
\end{tabular}

Values marked with the same letter do not differ significantly at $\mathrm{P} \leq 0.05$. n.s. - non significant differences

Interactions of varieties and years of research have been found in relations to planting before harvesting, heights to the first productive branching, sowing of the field, which indicates the individual reactions of the studied varieties to climatic conditions prevailing in particular years of research (Tables 6-7). It was observed that all varieties were distinguished by the largest planting diversity in the driest and warmest year of research. The population variety had the same number of plants in the first and second growing season, while in the restored hybrids, the differences in the value of this feature in the last year of the research were statistically insignificant. The studied morphotypes were distinguished by the highest height to the first productive branching in the first year of study, the value of which was the same in the PT248 variety in the last two years of research, and in the semi-dwarf morphotype in 2016-2017 and 2017-2018.

\section{Conclusions}

1. The use of the Aminoplant biostimulator in combination with foliar fertilizers containing sulphur and boron significantly increased the planting density (on average by $4.7 \%$ ), the stem thickness at the root (on average by $7.3 \%$ ), the height to the first productive branching (on average by $6.9 \%$ ), compared to the control object.

2. Foliar application of amino acids, boron, sulphur did not significantly increase the height of plants before harvesting and did not affect the deflection of the field. 
3. The morphotype determined the morphological characteristics of the plants before harvesting. The largest plant density was found in the semi-dwarf hybrids, while the population variety was distinguished by the largest thickness of the stem at the base, the height to the first productive branching. The plant height was the same in the population morphotype and the restored hybrid with a traditional growth type.

4. The climatic conditions in the vegetation period the experiment significantly influenced the examined elements of the field architecture.

5. Foliar fertilization should be used as a permanent element of winter rapeseed cultivation technology, therefore further research is needed to evaluate the performance of these preparations on various soil types.

Acknowledgements. The research was carried out under the research project No. 363/S/13, financed from a science grant by the Ministry of Science and Higher Education.

\section{REFERENCES}

[1] Babaeian, M., Tavassoli, A., Ghanbari, A., Esmaeilian, Y., Fahimifard, M. (2011): Effects of foliar micronutrient application on osmotic adjustments, grain yield and yield components in sunflower (Alstar cultivar) under water stress at three stages. - Afr. J. Agric. Res. 6(5): 1204-1208.

[2] Cheema, M. A., Sattar, A. Rasul, F., Saleem, M. F. (2012): Influence of different levels of potassium on growth, yield and quality of canola (Brassica napus L.) cultivars. - Pak. J. Agr. Sci. 49: 163-168.

[3] Chwil, S. (2016): The effect of foliar feeding under different soil fertilization conditions on the yield structure and quality of winter oilseed rape (Brassica napus L.). - EJPAU 19, \#02.

[4] Czarnik, M., Jarecki, W., Bobrecka-Jamro, D., Jarecka, A. (2015): The effects of sowing density and foliar feeding on yielding of winter oilseed rape cultivars. - Rośliny Oleiste Oilseed Crops 36(1): 60-68 (in Polish).

[5] El Habbasha, E. F., El Salam, M. (2009): Response of two canola varieties (Brassica napus L.) to nitrogen fertilizer levels and zinc foliar application. - Department of Plant Sciences, UC, Davis. https://escholarship.org/uc/item/68f0h22d.

[6] Fageria, N. K., Filho, B. M. P., Moreira, A., Guimarăes, C. M. (2009): Foliar fertilization of crop plants. - J. Plant Nutrition 32: 1044-1064.

[7] Kinaci, E., Gulmezoglu, N. (2007): Grain yield and yield components of triticale upon application of different foliar fertilizers. - Interciencia 32(9): 624-628.

[8] Jankowski, K. J., Hulanicki, P. S., Krzebietke, S., Żarczyński, P., Hulanicki, P., Sokólski, M. (2016a): Yield and quality of winter oilseed rape in response to different systems of foliar fertilization. - J. Elem. 21(4): 1017-1027. DOI: 10.5601/ jelem.2016.21.1.1108.

[9] Jankowski, K. J., Sokólski, M., Dubis, B., Krzebietke, S., Żarczyński, P., Hulanicki, P. S., Hulanicki (2016b): Yield and quality of winter oilseed rape (Brassica napus L.) seeds in response to foliar application of boron. - Agricultural and Food Science 25: 164-176.

[10] Jarecki, W., Bobrecka-Jamro, D. (2008): Reaction of winter rape to the extra feeding of its leaves. - Annales Universitatis Mariae Curie-Skłodowska Lublin - Polonia LXIII(2)E: 86-96.

[11] Jarecki, W., Buczek, J., Bobrecka-Jamro, D. (2019): The response of winter oilseed rape to diverse foliar fertilization. - Plant Soil Environ. 65: 125-130. 
[12] Kaur, M., Kumar, S., Kaur, A. (2019): Effect of foliar application of nitrogen, phosphorus and sulphur on growth and yield of Gobhi Sarson (Brassica napus L.) in central Punjab. Journal of Oilseed Brassica 10(1): 47-50.

[13] Kinaci, E., Gulmezoglu, N. (2007): Grain yield and yield components of triticale upon application of different foliar fertilizers. - Interciencia 32(9): 624-628. doi.org/10.1016/S0308-521X(01)00023-3.

[14] Kocoń, A. (2009): Effectiveness of foliar feeding of wheat and winter rape with selected fertilizers under conditions of optimal fertilization and soil moisture. - Annales Universitatis Mariae Curie-Skłodowska Sectio E, Agricultura 64(2): 23-28 (in Polish).

[15] Noreen, S., Fatima, Z., Ahmad, S., Athar, H. R., Ashraf, M. (2018): Foliar Application of Micronutrients in Mitigating Abiotic Stress in Crop Plants. - In: Hasanuzzaman, M., Fujita, M., Oku, H., Nahar, K., Hawrylak-Nowak, B. (eds.) Plant Nutrients and Abiotic Stress Tolerance. Springer, Singapore.

[16] Przybysz, A., Małecka-Przybysz, M., Słowiński, A., Gawrońska, H. (2008): The Effect of Asahi SL on Growth, Efficiency of Photosynthetic Apparatus and Yield of Field Grown Oilseed Rape. - In: Dąbrowski, Z. T. (ed.) Monographs Series: Biostimulators in Modern Agriculture: Field Crops, Editorial House Wieś Jutra, Warsaw, pp. 7-17.

[17] Rabiee, M., Kavosi, M., Vahed, H. S., Kehal, P. T. (2013): Effect of concentration and time of foliar spraying of nitrogen fertilizer on grain yield and important traits of rapeseed (Brassica napus L.) cv. Hyola 401. - Journal of Science and Technology of Agriculture and Natural Resources 17(64): 43-53 ref.19.

[18] Riki, G., Mobasser, H. R., Ganjali, H. R. (2014): Effect of iron and manganese foliar spraying on some quantitative characteristics of canola. - International Journal of Biosciences 5(1): 61-68.

[19] Sikorska, A., Gugała, M., Zarzecka, K. (2018): Response of winter rapeseed to biostimulator application and sowing method. Part I. Field architecture elements. - Acta Sci. Pol. Agricultura 17(4): 205-214.

[20] Singh, J., Singh, M., Jain, A., Bhardwaj, S., Singh, A., Singh, D. K., Bhushan, B., Dubey, S. K. (2013): Anintroduction of Plant Nutrients and Foliar Fertilization: A Review. In: Precision farming: a new approach. - Daya Publishing Company, New Delhi, pp. 252320.

[21] Skowera, B. (2014): Changes of hydrothermal conditions in the Polish area (1971-2010). Fragm. Agron. 31(2): 74-87 (in Polish).

[22] Szczepanek, M., Bech, A. (2019): Technology of winter oilseed rape with foliar fertilization. - Acta Sci. Pol. Agricultura 18(1): 39-47.

[23] Szewczuk, Cz., Sugier, D. (2009): General characteristics and types of foliar fertilizers offered on the Polish market. - Annales UMCS. s. E. LXIV(1): 29-36 (in Polish).

[24] World Reference Base for Soil Resources (2014): International Soil Classification System for Naming Soils and Creating Legends for Soil. Field Experiment. - FAO, WorldSoil Resources Reports, 106, Rome. http://www.fao.org.

[25] Yuncai, H., Schmidhalter, U. (2005): Drought and salinity: A comparison of the effects of drought and salinity. - J. Plant Nutr. Soil Sci. 168: 541-549. 